
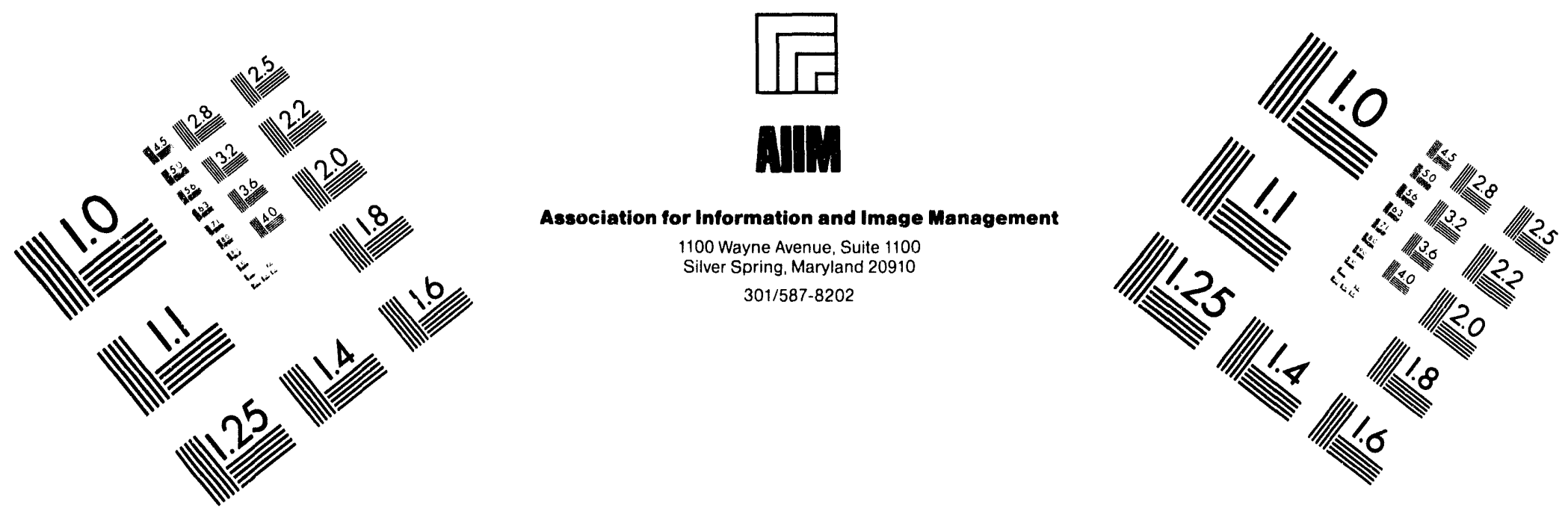

\title{
Centimeter
}

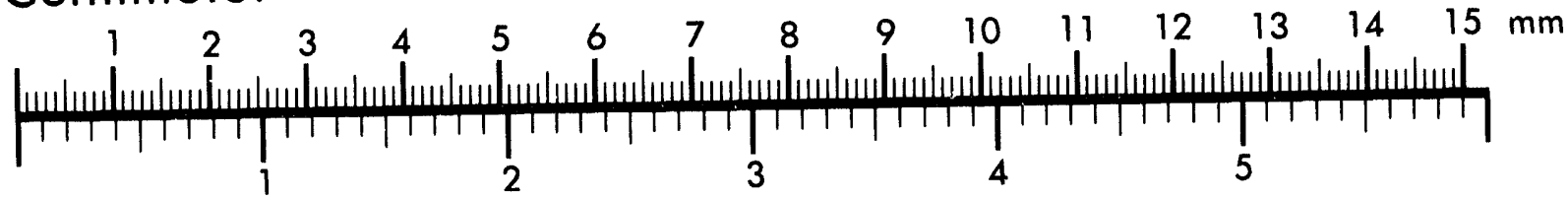
Inches
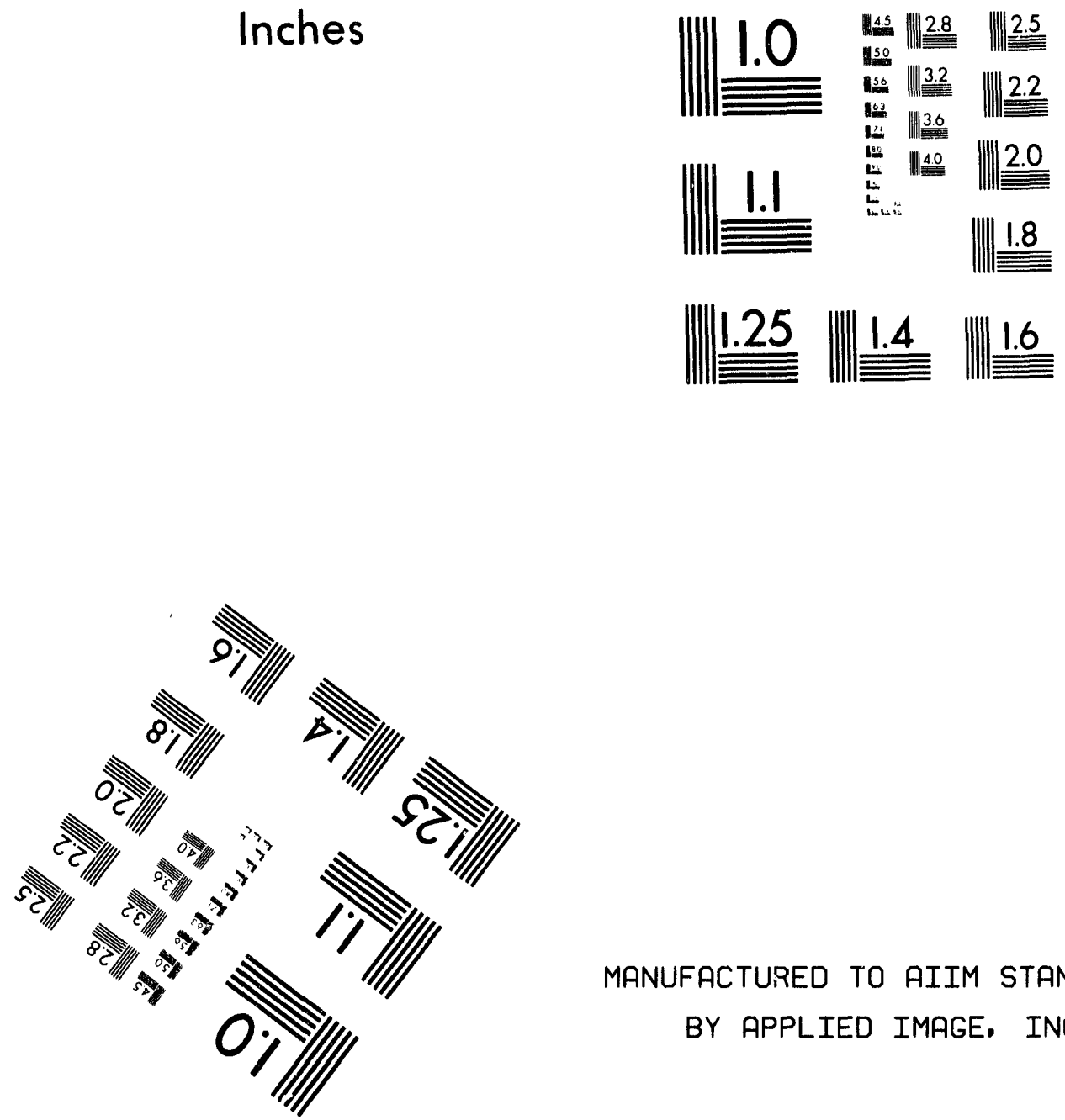

MANUFACTURED TO AIIM STANDARDS

$$
\text { BY APPLIED IMAGE. INC. }
$$

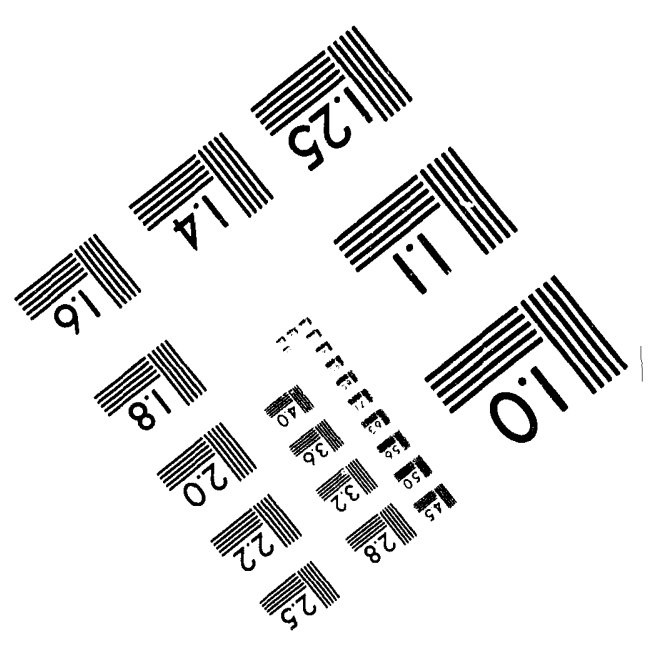



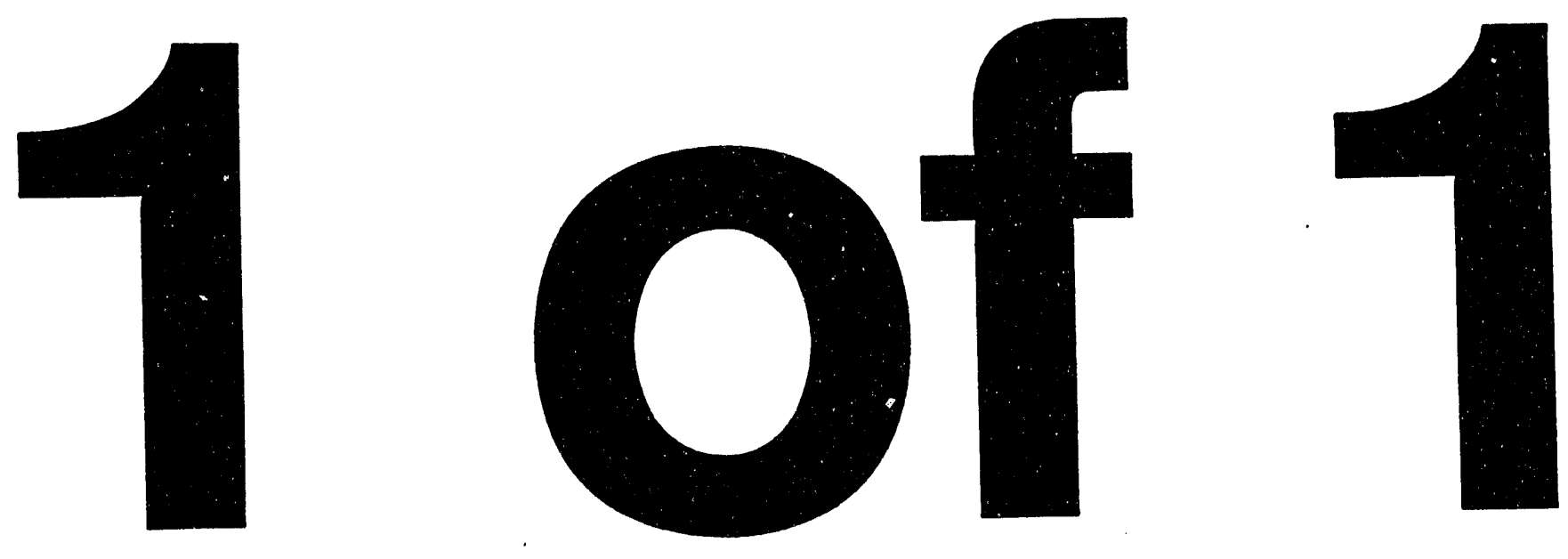
DOE/RL-94-74

Revision 0

\section{Implementation Guide for Hanford Analytical Services Quality Assurance Plan}

Date Published

September 1994

Prepared for U.S. Department of Energy Office of Environmental Restoration and Waste Management

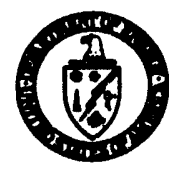

United States

Department of Energy

P.O. Box 550

Richland, Washington 99352

Approved for Public Release 


\section{Contents}

Acronym List $\ldots \ldots \ldots \ldots \ldots \ldots \ldots \ldots \ldots \ldots \ldots \ldots \ldots \ldots \ldots \ldots \ldots$ iv

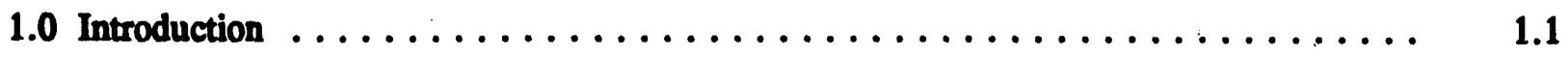

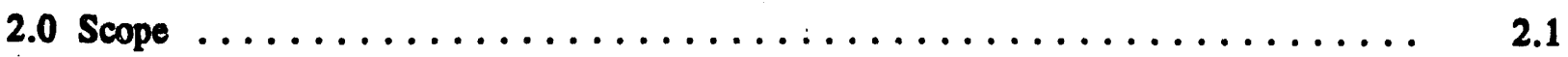

3.0 Organization and Personnel Responsibilities $\ldots \ldots \ldots \ldots \ldots \ldots \ldots \ldots \ldots \ldots$

4.0 Logic Flow and Schedule $\ldots \ldots \ldots \ldots \ldots \ldots \ldots \ldots \ldots \ldots \ldots \ldots \ldots$

5.0 HASQAP Implementation Activities $\ldots \ldots \ldots \ldots \ldots \ldots \ldots \ldots \ldots \ldots \ldots$

5.1 HASQAP $\ldots \ldots \ldots \ldots \ldots \ldots \ldots \ldots \ldots \ldots \ldots \ldots \ldots \ldots \ldots \ldots \ldots$

5.2 Regulatory and Program Reviews $\ldots \ldots \ldots \ldots \ldots \ldots \ldots \ldots \ldots \ldots$

5.3 Laboratory Implementation Activities $\ldots \ldots \ldots \ldots \ldots \ldots \ldots \ldots \ldots \ldots$

6.0 References $\ldots \ldots \ldots \ldots \ldots \ldots \ldots \ldots \ldots \ldots \ldots \ldots \ldots \ldots \ldots \ldots \ldots \ldots \ldots . \ldots \ldots \ldots$

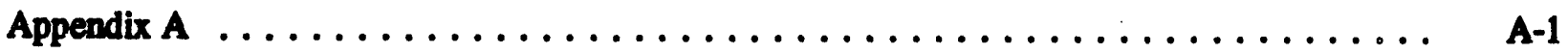

Figures

3.1 HASQAP Implementation Team $\ldots \ldots \ldots \ldots \ldots \ldots \ldots \ldots \ldots \ldots \ldots \ldots$

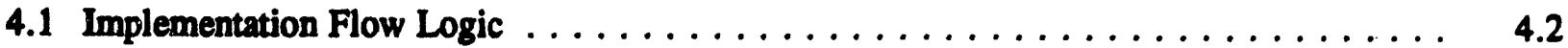

4.2 Implementation Schedule $\ldots \ldots \ldots \ldots \ldots \ldots \ldots \ldots \ldots \ldots \ldots \ldots \ldots \ldots$

\section{Tables}

4.1 Completion Dates for Major U.S. Department of

Energy, Richland Operations Ofice Milestones 


\section{Acronym List}

ACL
BHI
EAL
HASQAP
HLAN
HWMA
PNL
QAP
RL
Tri-Party Agreement
WHC
WSCF

Analytical Chemistry Laboratory

Bechtel Hanford, Inc.

Environmental Analytical Laboratory

Hanford Analytical Services Quality Assurance Plan

Hanford Local Area Network

(Washington State) Hazardous Waste Management Act

Pacific Northwest Laboratory

quality assurance plan

U.S. Department of Energy, Richland Operations Office

Hanford Federal Facility Agreement and Consent Order

Westinghouse Hanford Company

Waste Sampling and Characterization Facility 


\subsection{Introduction}

This implementation guide for the Hanford Analytical Services Quality Assurance Plan (HASQAP), DOE/RL-94-55, Revision 0, (RL 1994) was developed by the U.S. Department of Energy, Richland Operations Office (RL) Waste Management Division, Analytical Services Branch. This plan formally presents RL's direction for Hanford Sitewide implementation of the HASQAP.

The HASQAP establishes a uniform standard for quality requirements to meet U.S. Department of Energy Order 5700.6C, Quality Assurance (10 CFR 830.120, "Quality Assurance Requirements"), and is intended to satisfy the Hanford Federal Facility Agreement and Consent Order (Tri-Party Agreement) (Ecology et al. 1994) requirement for "Guidance on Preparation of Laboratory Quality Assurance Plans" (see Sections 6.5 and 7.8 and Appendix F of the Tri-Party Agreement). The quality assurance criteria specified in the HASQAP shall serve as a baseline for implementing quality management systems for the laboratories that provide analytical services, for data requesters and users, and for oversight organizations that monitor the data-generation process. Affected organizations shall implement the HASQAP requirements that are applicable to their work scope. Full implementation of the HASQAP is scheduled to occur by August 1995. RL will work with the U.S. Environmental Protection Agency (EPA) and Washington State Department of Ecology (Ecology) to have the HASQAP document incorporated into Appendix F of the Tri-Party Agreement by early Fiscal Year 1996. 


\subsection{Scope}

This implementation guide establishes the scope, identifies the activities, and provides the logic flow and schedule (See Section 4.0) for implementing the HASQAP. All Hanford Site laboratories managed by RL contractors and all commercial laboratories under contract to Westinghouse Hanford Company (WHC), Pacific Northwest Laboratory (PNL), or Bechtel Hanford, Inc. (BHI) that are used to perform sample analyses under the Resource Conservation and Recovery Act of 1976 (RCRA), Comprehenstue Environmental Response, Compensation, and Liability Act of 1980 (CERCLA), and/or Washington State Hazardous Waste Management Act (HWMA) (as delineated in the Tri-Party Agreement) shall comply with the HASQAP. Laboratories that use analytical techniques not specifically identified by these regulations, but use the techniques in response to Hanford Site remediation, will also comply with the HASQAP.

The primary Hanford Site laboratories performing sample analyses under the RCRA, CERCLA, and/or the HWMA are as follows:

- 222-S Laboratory

- Waste Sampling and Characterization Facility (WSCF)

- Analytical Chemistry Laboratory (ACL)

- Environmental Analytical Laboratory (EAL)

- Commercial laboratories that support this work scope.

Hanford Site laboratories and/or organizations that perform sample analyses under regulatory requirements not specified in the Tri-Party Agreement or for nonregulatory analyses, such as processsample analysis, are encouraged to use the QA concepts found in the HASQAP. Work performed by these laboratories and/or organizations identified to come under the HASQAP shall be included in the RL contractors' laboratory implementation plans (see Section 5).

Field screening activities, such as the Sampling and Mobile Laboratories do not fall under the requirements of HASQAP and are not included under this RL HASQAP Implementation Guide. 


\subsection{Organization and Personnel Responsibilities}

The Hanford Analytical Sarvices Council (HASC), consisting of the RL Analytical Services Branch manager and Hanford Site laboratory management representatives, has overview responsibility for implementing this HASQAP. The HASC shall designate a HASQAP Implementation Coordinator and Integrator (ICI). This person shall provide Sitewide coordination and integration of the implementation process and provide progress reports to the HASC. Each Hanford Site contractor shall designate an ICI to represent his or her company. The ICI shall have primary responsibility for satisfying commitments from this implementation guide. The contractor ICI will work with the HASC ICI to ensure Sitewide coordination and integration of that contractor's implementation activities to achieve consistency in the interpretation and application of the HASQAP requirements and guidelines. An RL Analytical Services Branch representative will be an integral part of the ICI team providing DOE oversight. (See Figure 3.1).

Each contractor shall establish roles and responsibilities (functions) for the personnel who will be responsible for the company's implementation of the HASQAP. Each contractor shall assign individuals to these functions. The assigned personnel will work with their company's ICI to achieve appropriate and uniform implementation of the HASQAP.

During the implementation period covered by this guide, two revisions to the HASQAP are scheduled. The team originally responsible for developing the HASQAP, the HASQAP Development Team, shall be designated by RL and the Hanford Site contractors to continue the process, responding to questions about HASQAP requirements and guidance and recommending changes to the HASQAP based on comments received during implementation. The HASC shall review and concur with the recommended changes. The RL Analytical Services Branch, acting for RL Waste Management Division, shall approve the changes through the appropriate document change-control process.

The ICI Team and HASQAP Development Team shall work together during implementation to identify potential issues and to seek timely resolution of those issues. This interaction between these teams is necessary to ensure the efficiency of the implementation process with identification and resolution of implementation; i.e., interpretation and application, issues and with appropriateness and responsiveness to changes resulting from revisions to the HASQAP. 


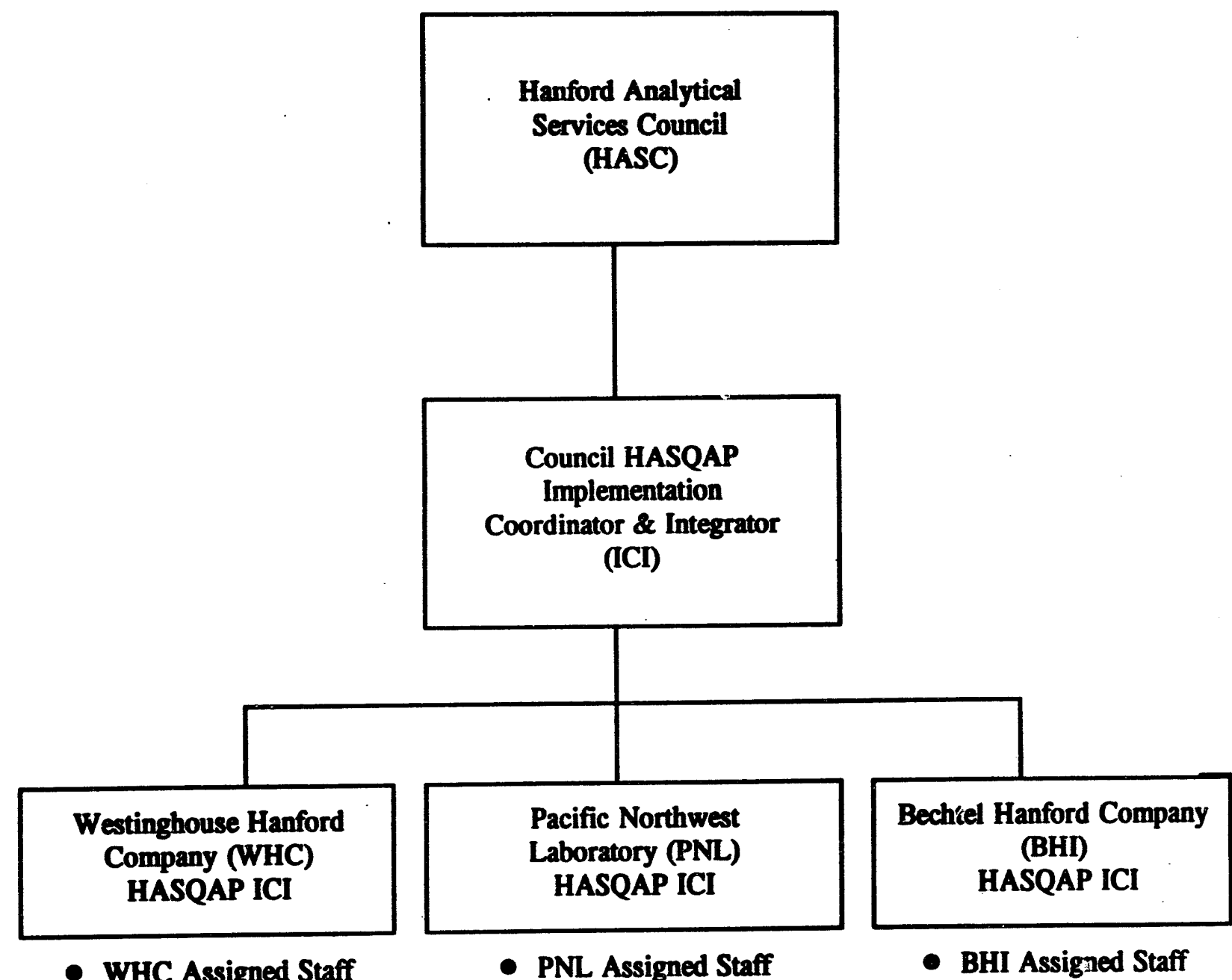

Figure 3.1. HASQAP Implementation Team 


\subsection{Logic Schedule and Flow}

The logic flow and schedule for implementing the HASQAP are shown in Figures 4.1 and 4.2, respectively. RL major milestones for contractors and their completion dates are listed in Table 4.1.

Table 4.1. Completion Dates for Major U.S. Department of Energy, Richland Operations Office Milestones

\begin{tabular}{|c|c|}
\hline Milestone & Completion Date \\
\hline $\begin{array}{l}\text { HASQAP (Revision 1) revisions submitted to } R L \text { for approval } \\
\text { QAP (and/or quality assurance manuals) implemientation plans } \\
\text { completed and submitted to } R L \text { for approval }\end{array}$ & $\begin{array}{l}\text { December 15, } 1994 \\
\text { January 16, } 1995\end{array}$ \\
\hline $\begin{array}{l}\text { Contractor-approved laboratory QAPs transmitted to RL for } \\
\text { submittal to Ecology and EPA }\end{array}$ & August 1, 1995 \\
\hline HASQAP fully implemented & August 31, 1995 \\
\hline
\end{tabular}

$$
\begin{aligned}
& \text { Ecology = Washington State Department of Ecology } \\
& \text { EPA } \quad=\text { U.S. Environmental Protection Agency } \\
& \text { HASQAP = Hanford Analytical Services Quality Assurance Plan } \\
& \text { QAP = quality assurance plan } \\
& \text { RL = U.S. Department of Energy, Richland Operations Office } \\
& \text { Tri-Party } \\
& \text { Agreement }=\text { Hanford Federal Facility Agreement and Consent Order }
\end{aligned}
$$

The logic flow and these milestones are described in Section 5.0. 


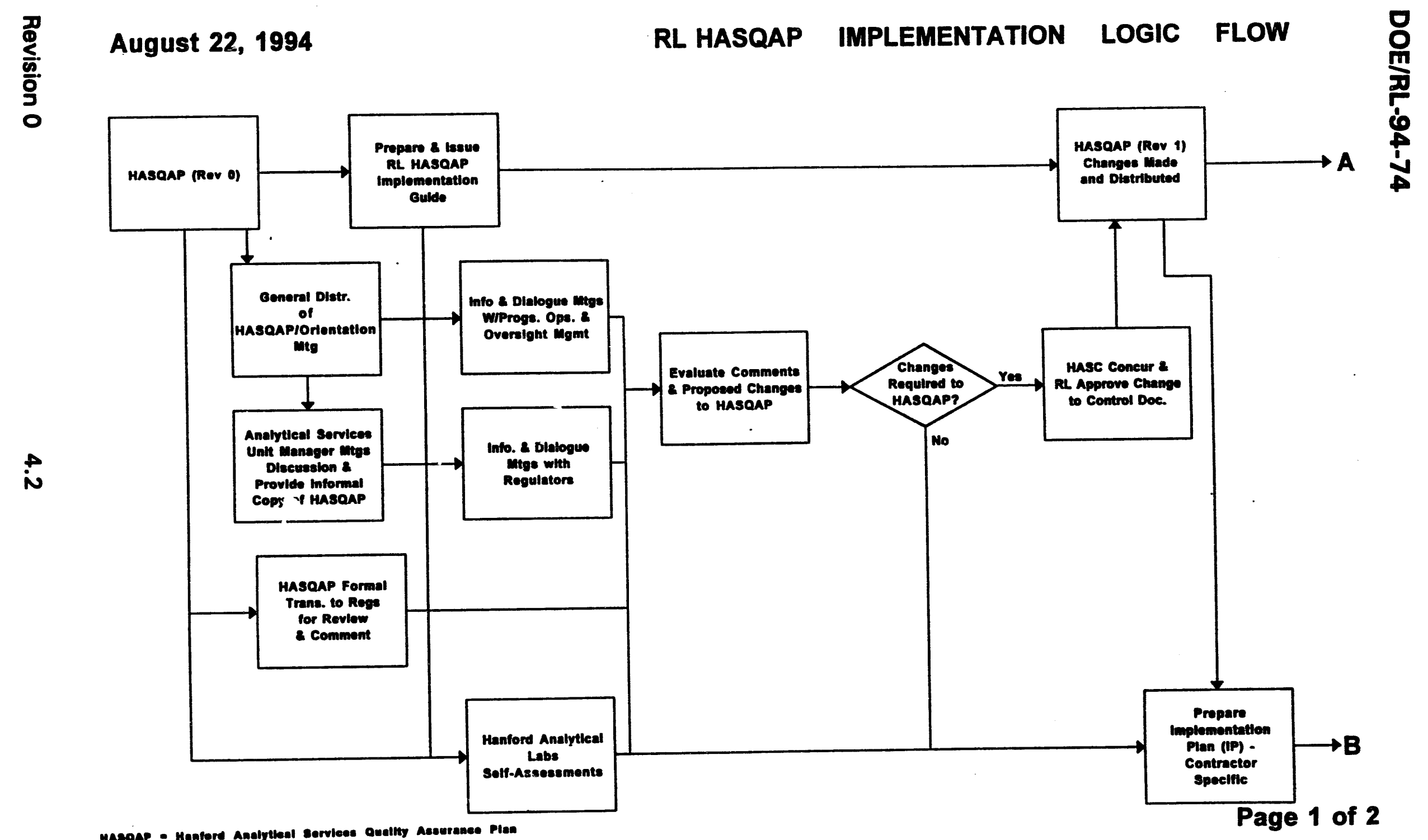

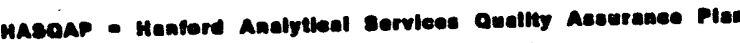
mase - Mentord Anelytieal sorvicos Counell

TPA - Irt-Party Agreoment

RL - U.8. Department of Energy. Mlehland Oporatbone

Figure 4.1. Implementation Logic 
August 22, 1994

RL HASQAP IMPLEMENTATION LOGIC FLOW

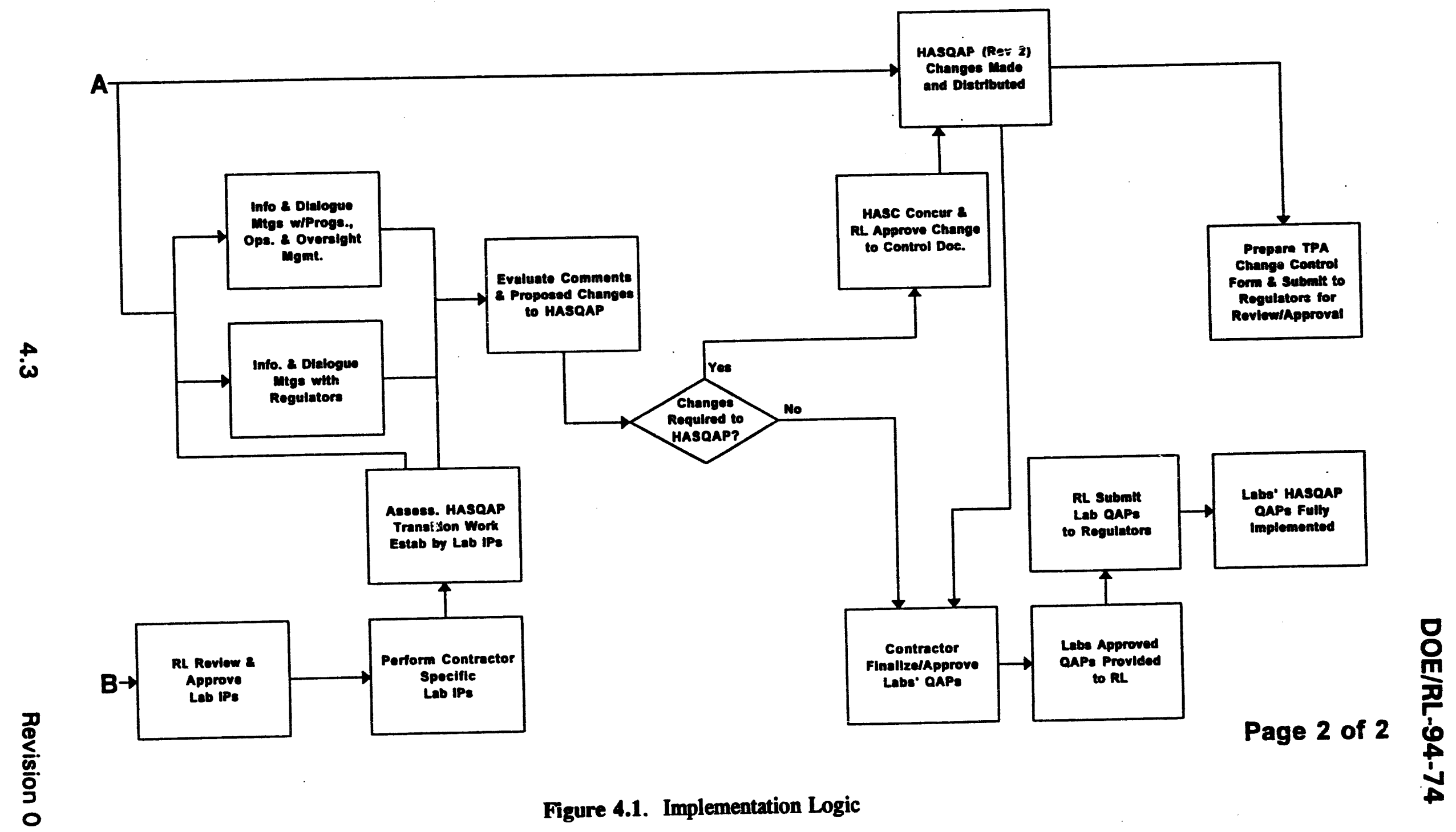


HANFORD ANALYTICAL SERVICES QUALITY ASSURANCE IMPLEMENTATION PLAN

$\frac{\bar{c}}{3}$

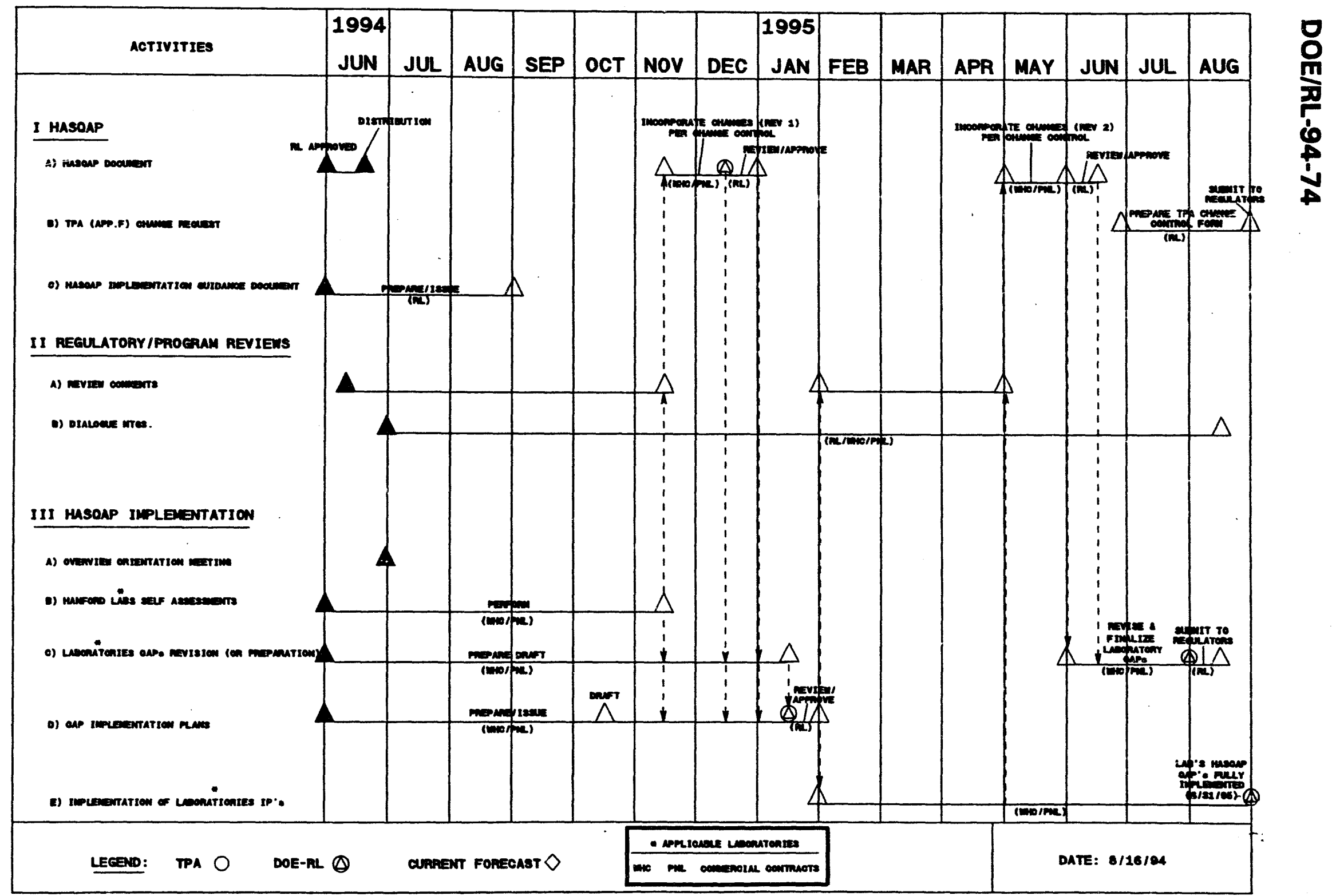

Figure 4.2. Implementation Schedule 


\subsection{HASQAP Implementation Activities}

The HASQAP implementation activities described in this section follow the logic flow and the implementation schedule (see Figures 4.1 and 4.2).

\subsection{HASQAP}

The HASQAP was approved by $\mathbf{R}^{\mathbf{T}}$. on May 31, 1994, and distribution was completed in early June. During the inplementation phase of the HASQAP in Fiscal Year 1995, two revisions are scheduled.

An evaluation of the HASQAP for Sitewide use shall be provided by RL programs and affected Hanford Site contractors. A Help-Line electronic mail (cc:mail) box has been installed on the Hanford Local Area Network (HLAN). This mail box shall allow implementors to ask questions and obiain timely answers, and to propose changes to the HASQAP. (For access to the mail box, see Appendix A.) The HASQAP Development Team (see Section 3), has been designated to respond to these questions. The team shall review, evaluate, and advise the $R \mathbf{L}$ Analytical Services Branch on potential changes to the HASQAP. The HASQAP (Revision 1) shall be submitted to RL for approval by December 15, 1994. Changes to the HASQAP that are justified shall be made through document change control authorized by the RL Waste Managennent Division.

During the third quarter of Fiscal Year 1995, when the final stages of the HASQAP are being implemented, a second revision to the HASQAP is planned that will incorporate required changes resulting from further review and assessment. Following this revision to HASQAP, RL shall prepare and issue a change control form to Ecology and the EPA() to include the HASQAP in Appendix F of the Tri-Party Agreement. The change form shall be submitted to the regulators by August 31, 1995. RL has set the inclusion of HASQAP in Appendix F as a goal to be achieved in early Fiscal Year 1996.

\subsection{Regulatory and Program Reviews}

In June of 1994, the RL Analytical Services Branch provided informal copies of the HASQAP to the regulators for review. In August, RL formally submitted copies of the HASQAP to the regulators requesting review and comments for incorporation into the HASQAP by November 1, 1994. From August through November, meetings are planned with RL programs, operations, and oversight organizations and Hanford Site contractors' representatives, and with representatives from Ecology and the EPA to provide HASQAP orientation information and to discuss implementation. Comments received shall be evaluated and, as appropriate, included in the HASQAP through document change control. During the laboratories' implementation phase, assessments will be performed as identified and scheduled in each RL contractor's laboratory implementation plan. RL shall also perform independent assessments. The results of these assessments shall provide the basis for dialogue between the regulators, RL, WHC programs, and RL contractor (WHC, PNL, and BHI) laboratories for effectiveness of the HASQAP. Additional changes to the HASQAP may be necessary. Proposed

(a) These two organizations together are referred to as the regulators. 
changes will be reviewed and, as appropriate, incorporated through document change control athorized by the RL Waste Management Division.

\subsection{Laboratory Implementation Activities}

Each Hanford Site contractor affected by the HASQAP implementation shall identify personnel responsible for the following activities:

- perform a laboratory self-assessment

- revise (or prepare) the laboratory quality assurance plan(s) (QAP) (and/or quality assurance manuals) to implement the HASQAP requirements

- prepare the laboratory QAP implementation plan

- perform the activities in the laboratory implementation plan.

A roles-and-responsibilities matrix with personnel identified for implementing the laboratory's compliance to the HASQAP shall be established and maintained by each RL contractor. These personnel shall be responsible for working with their company's implementation coordinator and integrator to successfully implement the HASQAP (see Section 3).

An overview orientation training session was held June 30, 1994. Laboratory managers, supervisors, laboratory leaders, program and project managers, and representatives from quality assurance and the regulators attended the training session, which addressed the important subject areas of the HASQAP. The training session also initiated the HASQAP implementation process.

During the implementation of the HASQAP across the Hanford Site, the affected laboratories shall be consistent in their interpretation and application of the HASQAP requirements. The contractordesignated ICI Team and the HASQAP Development Team will work together to ensure consistency in HASQAP interpretation and application and to determine the appropriateness of changes to the HASQAP. Questions, requests for information, comments, or proposed changes to the HASQAP can be sent to the HASQAP Help Line (see Appendix A).

Each affected Hanford Site laboratory shall perform a self-assessment for implementing the requirements and guidance specified in the HASQAP, including identification of deficiencies in the current laboratory documentation (e.g., procedures requiring revisions). This self-assessment shall also identify, justify, and provide the basis for any additional resources required to implement the HASQAP. This self-assessment is internal to each contractor and provides the contractor's basis for establishing resource needs and for developing its laboratory QAP implementation plan.

Each affected Hanford Site laboratory shall revise (or prepare) applicable QAPs (and/or quality assurance manuals) to implement the requirements of the HASQAP. Each affected contractor shall prepare the draft laboratory QAPs for the primary laboratories (see Section 2.0). The draft laboratory QAPs are scheduled for completion January 16, 1995. Drafts of the laboratories' implementation plans shall be completed by October 15, 1994. The final contractor implementation plan shall be completed 
by January 16,1995 . On this date, the contractor laboratory QAP implementation plans are to be submitted to $\mathbf{R} \mathbf{L}$ for approval.

Each contractor laboratory implementation plan shall document the.logic, task descriptions, and detailed schedule for changing from the existing to the revised (or new) laboratory QAP (and/or quality assurance manuals). Each contractor's plan shall address revisions to its commercial laboratory contracts. Revisions made to these contracts and their implementation shall be completed by August 31, 1995, concurrent with the HASQAP being fully implemented at Hanford Site laboratories. Each contractor implementation plan shall ensure that the laboratory always operates under the provisions of a QAP (and/or quality assurance manuals).

The RL shall review (and obtain revisions from the contractors, as appropriate) and approve the laboratory implementation plans by February 1, 1995. On this date, the contractors shall initiate their laboratory's implementation plans to come into compliance with the HASQAP. The RL will use each contractor's implementation plan(s) and schedule(s) to monitor that contractor's performance on implementing the HASQAP. Laboratory managers will provide status to the HASC monthly.

As the laboratories progress in accomplishing the implementation plan activities, the assessments identified in the laboratories' implementation plans shall be performed. These assessments shall check for compliance to the HASQAP requirements and guidances. RL shall perform its independent assessments during the same period. Results of these assessments shall provide the basis for dialogue between regulators, RL/WHC programs, and RL contractor (WHC, PNL, and BHI) laboratories about the effectiveness of the HASQAP. Additional changes to the HASQAP may be necessary. Changes proposed for the HASQAP (Revision 2) will be evaluated and, as appropriate, incorporated through document change control authorized by the RL Waste Management Division.

Following completion of the HASQAP (Revision 2), the RL contractors shall finalize and approve their laboratories' QAPs and transmit copies to RL by August 1, 1995. RL shall submit these QAPs to the regulators for review as secondary documents in fulfillment of the Tri-Party Agreement requirements given in "Quality Assurance," Sections 6.5 and 7.8 of the Tri-Party Agreement. On August 31, 1995, the RL contractors will complete full implementation with the applicable laboratories operating under the HASQAP. 


\subsection{References}

10 CFR 830.120. 1994. U.S. Department of Energy. "Quality Assurance Requirements." U.S. Code of Federal Regulations.

Comprehenstve Environmental Response, Compensation, and Liability Act of 1980. 42 U.S.C. 9601 et seq.

Resource Conservation and Recovery Act of 1976. 42 U.S.C. 6901 et seq.

State of Washington Hazardous Waste Management Act of 1976. Revised Code of Washington. Chapter 70.105 et seg. Olympia, Washington.

U.S. Department of Energy (DOE). 1991. Quality Assurance. DOE Order 5700.6C.

U.S. Department of Energy, Richland Operations Office (RL). 1994. Hanford Analytical Services Quality Assurance Plan. DOE/RL-94-55, Revision 0.

Washington State Department of Ecology, U.S. Environmental Protection Agency, and U.S. Department of Energy, Richland Operations Office. 1994. Hanford Federal Facility Agreement and Consent Order. 


\section{DOE/RL-94-74}

\section{Appendix A}

\section{HASQAP Help-Line Access}




\section{Appendix A}

HASQAP Help-Iine Accens

- Access Hanford Local Area Network (HLAN)

- Access electronic mail (cc:Mail)

- Address message to "Hanford Analytical Service QA"

- Prepare message to be sent (i.e., ask questions, request information, or propose changes to the Hanford Analytical Services Quality Assurance Plan (HASQAP).

For proposed changes to the HASQAP, the commentors are requested to use their company's form for making formal comments to documents. For the U.S. Department of Energy, Richland Operations Office and Westinghouse Hanford Company, the form is the Review Comment Record (RCR); for Pacific Northwest Laboratory (PNL), the form is the Document Review Record (DRR). See the following instructions for access to these forms.

The instructions for access to the RCR form are:

- Load HLAN System Resource-WordPerfect*

- Access Macros (Alt-F10)

- Respond to "Macro:" by typing "WEF011" and then striking the ENTER key. This step loads the RCR form into WordPerfect.

Once the RCR form is loaded into WordPerfect, general instructions are provided to ensure uniform usage and to establish basic requirements for initiation and control. The form can be filled out, edited, saved, and manipulated using the normal WordPerfect commands.

The PNL DRR form will be provided electronically to PNL commentors by Kay Hilty (PNL) (376-8466.)

* WordPerfect is a trademark of WordPerfect Corporation. 


\section{Distribution}

No. of

Copies

\section{ONSTIE}

23

U.S. Departinent of Energy, Richlend Operntions Office

A. V. Beard

G. M. Bell

C. J. Bosted

M. L. Burrell

R. P. Carter

C. E. Clark

J. M. Clark

J. W. Day

J. K. Erickson

M. J. Furmen

R. E. Gerton

E. D. Goller

J. D. Goodenough

R. F. Guercia

C. K. Resch

C. K. Liu

J. R. Noblo-Dial

J. E. Rasmuseen

A. D. Seruntz

R. K. Stowart

T. M. Stram

D. M. Whnek

Reading Room

9 Bechtel Hanford. Inc.

R. A. Carlson

H6-01

R. P. Henckel

M. C. Hughes

D. R. Jorden

J. H. Kessoer

W. H. Price

M. R. Schwab

C. Stacoy

T. M. Wintezak

H6-01

X5-55

$\mathrm{X} 2-10$

H4-23

N3-05

H6-05

H4-23

H4-79

2 Henford Environmental Health Foundation

M. K. Hamilton

J. K. Samuels

B5-03

B1-61

No. of

Copies

ONSIUE

1 ICE Kriser Enqineen Henford

R. W. Henderson G4-07

35 Pacific Northwest Laboratory

J. K. Ace K3-18

T. L. Almoida P7-25

D. A. Anderson P7-27

R. M. Bean P8-08

O. P. Bredt P7-27

S. K. Fadeff P8-08

W. B. Gintner P7-27

L. R. Greenwood P7-22

C. O. Harvey P7-22

E. W. Hoppe P7-22

T. Y. Hoaka $\quad$ B1 -40

A. G. King P7-22

B. C. King P7-72

G. S. Klinger P7-22

D. W. Koppenal P7-07

R. J. Kuhl-Klinger P7-27

J. M. Latkovich P7-27

P. M. Lindsay $\quad$ P7-27

M. L. Martin T6-20

K. L. Manke K6-86

S. G. McKinley P7-22

P. J. Mellinger P7-22

R. W. Pennington K3-43

J. M. Robbins P7-22

S. A. Schubert P7-22

P. K. Schuette K1-09

K. L. Silvers P7-27

R. T. Steole P7-22

R. S. Strebin P8-08

R. W. Stromat P7-22

C. D. Taylor B1-40

B. L. Thomas B1-34

J. M. Tingey P7-25

M. W. Urie P7-22 


\section{Distribution (cont)}

No. of

Copies

ONSTYE

117 Weatinghoure Henford Company

\begin{tabular}{|c|c|}
\hline 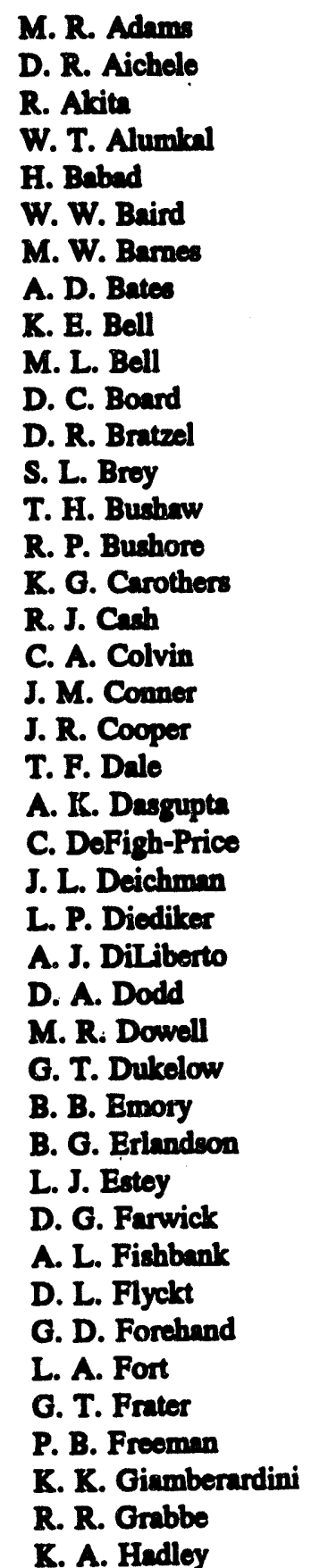 & $\begin{array}{l}H 6-30 \\
\text { HO-41 } \\
\text { T6-20 } \\
\text { S7-85 } \\
\text { S7-30 } \\
\text { T6-16 } \\
\text { T6-16 } \\
\text { H4-19 } \\
\text { T6-06 } \\
\text { T6-16 } \\
\text { S1-57 } \\
\text { S7-31 } \\
\text { T6-12 } \\
\text { T6-30 } \\
\text { T6-07 } \\
\text { R1-51 } \\
\text { S7-15 } \\
\text { S6-20 } \\
\text { L4-75 } \\
\text { H4-19 } \\
\text { T6-20 } \\
\text { S3-28 } \\
\text { S7-30 } \\
\text { H4-19 } \\
\text { T1-30 } \\
\text { H6-32 } \\
\text { T6-50 } \\
\text { S3-28 } \\
\text { S7-15 } \\
X 3-70 \\
\text { H6-20 } \\
\text { T5-50 } \\
\text { H4-16 } \\
\text { S5-51 } \\
\text { T7-38 } \\
S 7-31 \\
S 4-54 \\
\text { S7-30 } \\
H 6-06 \\
\text { T6-06 } \\
\text { S3-28 } \\
\text { R3-56 }\end{array}$ \\
\hline
\end{tabular}

No. of

Copies

ONSTUE

D. L. Halgrea $\$ \mathbf{5 6 - 7 0}$

M. J. Hall T6-07

V. W. Hall H4-19

C. S. Fialler R2-12

W. H. Hamilton N3-10

K. L. Hladak H5-33

C. S. Homi R2-12

D. G. Horton H6-06

J. L. Huckaby \$7-15

S. L. Huggins H4-23

J. E. Hyatt $\quad$ H4-19

T. G. Ibsen $\quad \mathbf{S 3 - 3 0}$

M. A. Islam H5-55

L. Jensen T6-07

J. R. Jewett T6-09

G. D. Johnson $\quad$ G1-19

G. D. Johnson S7-15

S. M. Joyce H4-19

F. M. Jungfleisch T7-38

K. H. Kary \$3-28

E. J. Kosiencic T6-16

J. G. Kristofzski T6-06

G. J. LeBaron S6-19

W. D. Leggett T6-07

J. W. Lentech S7-15

D. W. Lindeey $\quad$ L6-04

L. L. Lockrem $\quad \$ 3-90$

C. D. Luces $\quad$ X0-35

W. L. Louk T5-05

L. P. Markel T6-16

R. P. Marnhall T6-14

D. J. McCain \$7-30

N. O. McDuffio \$7-15

H. K. Meznarich T6-16

R. A. Mezmarich S3-27

J. R. Mobley H5-49

G. C. Mooers R3-85

P. M. Morant H4-19

J. N. Nansen N1-71

M. A. Payne \$7-14

P. R. Pretorius H4-25

J. R. Prilucik T6-24

K. N. Pool H4-23 


\section{Distribution (cont)}

No. of

Copies

ONSTTE

R. E. Raymond

R. J. Roberts

M. R. Romaos

L. M. Susali

M. J. Schliebe

R. D. Schreiber

J. A. Seamans

D. A. Sobelien

P. Sogall

J. P. Sloughter

W. Smith

D. R. Speer

G. A. Stantion

C. R. Stroup

C. S. Sutter

C. D. Suydam

R. W. Szolmeczia

L. H. Taylor

M. C. Thompson

R. R. Thompeon
No. of

Copies

\section{ONSITE}

R2-54

N3-13

T3-04

R2-12

S4-25

R2-12

N2-04

T6-16

H4-19

T6-07

T3-28

56-65

57-31

H4-19

T5-12

S3-31

L4-96

H4-23

T6-14

H6-32
W. S. Thompeon N3-05

D. M. Thornton T6-22

W. E. Toebe H6-10

D. A. Tumer \$7-15

T. B. Venezimo H6-10

O. S. Wang \$7-15

D. J. Watson X0-41

K. B. Wohner T6-50

W. I Winters T6-50

Central Files L8-04

OSTI (2) L8-07

6 Routing

R. M. Ecker

SEQUIM

M. J. Grahnm

P. M. Irving

K6-78

R6-98

K6-04

C. S. Sloane

K6-86 

